\title{
CHRISTELIKE ONDERWYS.
}

Aan die begin van 1948 het die Instituut vir Christelik-Nasionale Onderwys, 'n stigting van die Federasie van Afrikaanse Kultuurvereniginge na jarelange intensiewe studie 'n Beleid vir ons Christelik-nasionale Onderwys gepubliseer. Hierdie Beleid is saamgestel deur 'n groep manne uit alle vertakkinge van ons Christelik-nasionale volkslewe: uit aldrie ons Afrikaanse kerke en uit verskillende professies soos die onderwys, die reg, die kerk en die staat. Na publikasie van die Beleid is dit as die norm vir ons C.N.O. aanvaar deur ons drie Afrikaanse Kerke, ons vier Afrikaanse Onderwysersvereniginge, deur allerlei Afrikaanse Kultuurorganisasies. Die Beleid verteenwoordig dus die diepgvoelde oortuiging van die grootste deel van ons Afrikaners. In alle vrede is dit aanvaar, en dit het geskyn of die vrede op die gebied van ons C.N.O. bereik is.

Maar, die jaar 1949 het anders getuig. Heel aan die begin van 1949 is die Beleid van verskillende kante aangeval. Die aanvallers was en is nog deur die bank manne en vroue wat óf nie Afrikaansgesind is nie óf nie lidmate van die drie Afrikaanse kerke nie. In die reël is die aanval gevoer deur ons Engelssprekende mede-Suid-Afrikaners en veral deur Afrikaanssprekendes wat nie meer nasionaal voel nie en wat óf nie Christelik-gereformeerd is nie of in godsdienstige opsig vrywel liberaal dink. Nou kan ons hulle dit nie kwalik neem dat hulle nie met ons 
saamstem nie, maar wat ons hulle wel kan kwalik neem is dat hulle ons Beleid op 'n uiters vyandige wyse aangeval het en nog aanval. In ons Beleid word niemand van watter rigting ook al aangeval nie. Daarin word net positief en saaklik gestel wat ons C.N.O.-mense verlang insake die onderwys en opvoeding van ons kinders. Dit was en is inderdaad pynlik verrassend dat en hoe ons Beleid aangeval word. Die kritiek was en is deurgaans vyandig, vernietigend en negatief. Nergens word ondersoek of ons ' $n$ reg het om so 'n Beleid vir die onderwys en opvoeding van ons kinders saam te stel nie. Nergens word ondersoek of die Beleid 'n konstrukticwe bydrae is nie. En nergens is dit ondersoek of die Beleid ' $n$ konsekwente en eerlike deurdenking is van ons bepaalde standpunt. Indien 'n man die onderwysbeleid van 'n persoon of 'n groep persone wil beoordeel, moet jy tog in die eerste plek seker maak wat die lewens- en wêreldbeskouing van die persoon of groep is. 'n Onderwysbeleid is tog, soos selfs die moderne liberale opvoedkundige John Dewey dit in sy „Democracy and Education" sê, gegrond op 'n bepaalde lewenskeuse: jou lewenskeuse bepaal jou onderwys en opvoeding. En in die Beleid het ons presies niks anders gedoen as om 'n onderwysbeleid uit te werk op grond van ons C.N. lewens- en wêreldbeskouing nie. Dat ander mense-denkers en daders-met ons beleid nie saamstem nie-dit is hul saak en ons gun hulle dit. Hulle mag sê dat dit nie hul beginsel en beleid is nie, maar hulle mag as weldenkende mense nie so teen ons te kere gaan nie. Hulle moes liefs naas ons Beleid 'n eie Beleid saamgestel en gepropageer het. Hulle mag wel skerp teen 'n beleid ingaan as dit die staatslewe sou vernietig of die openbare sedes bederf-en ons Beleid doen nog die een nog die ander.

Nou, waarom val Engelssprekendes, Engelsgesinde Afrikaners, liberaalgesinde en selfs vrysinníge mense ons Beleid dan so vuur-warm aan? Ek vind slegs een verklaring vir hul optrede: die Engelssprekendes meen dat ons deur die Beleid van hulle Afrikaners wil maak en die liberaalgesindes weer dat ons van hulle gereformeerde Christene wil maak. Nou is nog die een nog die ander korrek. Ons het 'n Beleid ontwikkel vir die onderwys en opvoeding van die ruim 11/8 miljoen Afrikaners wat nog aan een van ons drie Afrikaanse kerke behoort. Wat die Engelssprekendes en die liberaal-gesindes vir die onderwys en opvoeding van hul kinders wil hê, is hul saak. Ons sal hulle niks in dic weg lê om 'n onderwys en opvoeding te kry ooreenkomstig hul lewenskeuse nic. Van dwang op andersdenkendes is daar in ons Beleid-en in ons optrede om die Beleid te verwesenlik in die praktyk van die opvoeding-nie die minste tekens nie. Daarenteen, ons is liefhebbers van die vryheid, en wat 
ons vir onsself vra, is ons bereid om aan andere te gun. Die agtergrond van die agitasie teen ons C.N.O.-Beleid is vrees en nie opvoedkundige belangstelling nie.

Die aanval rig hom teen ons verklaring van albei die terme: nasionaal en Christelik en selfs teen die gekoppelde term: Christelik-nasionaal.

Ek laat nou vir die huidige die aanval op ons term „nasionaal” daar, en gaan my verder beperk tot die aanval op ons term "Christelik."

Sowel deur Engelssprekende mede-Christene as deur liberaalvoelende Christene en heeltmal vrysinnige denkers is ons Beleid bestempel as „on-Christelik." Die idee agter die bestempeling is in die eerste plek nie dat ons definisie van Christelik on-Christelik is nie, maar dat dit onChristelik is om enige Beleid op andersdenkendes af te dwing. Daar stem ons met ons kritici volkome saam. As ons ons C.N.O.-Beleid op andere wou afdwing, sou die handeling inderdaad on-Christelik gewees het. Maar daar ons nie die minste idee het om ons beskouing op andere af te dwing nie, verval hierdie punt van kritiek. Ons Beleid is saamgestel om te dien as dokument van wat ons vir ons kinders wil hê. Andersdenkendes kan 'n soortgelyke beleid vir hul kinders formuleer-en ons beskou dit nie alleen as hul reg nie maar ook as hul plig.

' $n$ Ander aanval op ons bepaling van die begrip word weergegee in die volgende sinsnede wat deur 'n liberaal-Christelike Afrikaner ergens gebesig is. Hy sê naamlik dit: „Ek huldig die standpunt dat om Christelik te omskryf as ,Godsopenbaring in die Bybel soos dit in die Belydenisskrifte van ons drie Afrikaanse kerke uitgedruk is' blote onsin is." Nou, hier het ons 'n uiterste geval van iemand wat homself liberaal noem maar wat die standpunt van andersdenkendes bestempel as onsin! Hierdie man ken nog nie eers die eerste beginsels van liberalisme nie. 'n Eerlike denker sal nooit die ernstige oortuiginge van iemand anders as onsin bestempel nie; hy sal hoogstens net sê dat dit nie sy standpunt is nie. Nou het ons in ons Beleid baie duidelik gesê wat ons onder "Christelik" verstaan, en wel die bekende gereformeerde standpunt van ons voorvaders. Maar daarmee wil ons vir geen enkele oomblik sê dat daar geen ander Christene is as net die gereformeerde Christene nie. Nee, ons weet beter. Ons weet daar is Rooms-Katolicke en Protestantse Christene, daar is Anglikaanse, Lutherse en Calvinistiese Christene, daar is selfs Baptistiese, Sewende-Dag-Adventistiese en andere Christene. Moet ons nou soos hierdie kritikus al die andersdenkende Christene as „onsinnig” bestempel! Nee, ons doen dit nie. Ons sê maar net duidelikheidshalwe wat ons in ons Beleid onder "Christelik" verstaan en verstaan wil hẻ. 
Ten slotte is daar welmenende maar ook laat dunkende mense wat sê dat daar nie so iets as "Christelike" onderwys kan wees nie, en selfs nie mag wees nie.

Hulle sê in die eerste plek dat onderwys nou eenmaal maar net onderwys is. Hierin is hulle na ons mening verkeerd. Onderwys is nooit maar net onderwys nie; dit is maar altyd net 'n middel tot die totale opvoeding van die kind. As ons aan 'n kind onderwys gee, dan voed ons hom gelyktydig ook op. Daarmee wil ons net sê dat die vorming van hoof en hand, soos die deur die opsetlike onderwys geskied, altyd ook die hart, ja, die hele mens vorm en voed en grootmaak. Elke stukkie onderwys wat ek gee, vorm 'n inherente deel van die algemene opvoeding van die kind. Ons hou dus vol dat alle onderwys prinsipieel bepaal is. Ons lewens- en wêreldbeskouing bepaal dus ons hele onderwys. Selfs 'n vrysinnige denker soos John Dewey erken dit ruiterlik: daarom pleit hy vanuit sy standpunt vir 'n demokratiese onderwys (en opvoeding). Maar daarom pleit ons vanuit ons Christelike standpunt vir 'n Christelike onderwys (en opvoeding). Van meet af moet daar dus vir Christene 'n Christelike onderwys en opvoeding wees, en vir gereformeerde Christene 'n gereformeerd-Christelike onderwys en opvoeding. „Christelik" en onderwys kan dus nie teenstrydige begrippe uit bloot prinsipiële oogpunt wees nie: hulle vorm 'n eenheid vir die Christen, sy onderwys kan en mag niks anders as Christelik wees nie.

Maar nou kom ons teenstanders met die eenvoudige bewering dat ' $n$ feit 'n feit is, bv. $2+2=4$ is ' $n$ feit en nie 'n Christelike feit nie; ' $n$ feit is dieselfde vir Christen en nie-Christen. Nou wel, daaroor gaan die ook nie. Christene beweer nie dat die feite sgn. Christelike „feite," in bogenoemde sin, is nie. Daar is natuurlik die Christelike heilsfeite soos die geboorte, lyde en sterwe van Christus Jesus, sy versoening en verlossing. Maar die sgn. "sekulêre" feite waarvan $2+2=4$ 'n voorbeeld is, is as sodanig nie Christelik nie. Maar, dit gaan nie om die feite as sodanig nie. Dit gaan om ons houding en interpretasie. Die houding van die ongelowige by die vasstelling en ontdekking van ' $n$ feit is 'n houding van selfverheerliking: Ek, die grote, het hierdie feit gevind; en daarom roep hy uit: eureka-ek het gevind! Die houding van die gelowige Christen is heel anders: nie Ek nie maar God! Dit is nie Ek wat die feit gevind het nie maar dit is God wat dit aan my geopenbaar het. Maar daar is ook ' $n$ verskil in interpretasie en aanwending. Let maar net op die verskil tussen die gelowige Christen en die ongelowige ten opsigte van die verstaan en gebruik van die kennis en vaardigheid deur onderwys verkry. Die ongelowige se hoogste ideaal met sy kennis en vaardigheid is sosiale bruikbaarheid in die allergunstige geval en persoonlike 
voordeel in die meeste gevalle. Die kennis en vaardigheid wat die ongelowige deur die onderwys verkry het, verstaan en gebruik hy in die reël in diens van die mens en van homself. Om dit op sy ergste uit te druk: deur die onderwys wil hy in die wêreld vorentoe kom. Hy wil hom vir 'n betalende ,job" bekwaam. Daarteenoor staan die gelowige Christen heeltemal anders teen die verwerwing van en die verwerfde kennis en vaardigheid. Hy sien die onderwys as 'n middel wat God tot sy beskikking gestel het om hom te bekwaam vir die „roeping" waarin God hom wil stel. Sy toekomstige werk is nie om homself nie maar alleen om God, want sy hele lewensroeping is om te leef tot die eer van sy God. Daarom benader die gelowige Christen die onderwys van die sgn. sekulêre feite heeltemal anders as die ongelowige, en daarom verstaan en gebruik hy die feite ook heeltemal anders. Ook uit hierdie kardinale hoek beskou, is Christelike onderwys essensieel, en essensieel anders as nie-Christelike onderwys. In die Christelike onderwys interpreteer ons die sgn. sekulêre feite in die lig van die ewigheid: in $U$ lig sien ons alleen die lig. Geen enkele sekulêre feit is (of kan wees) in stryd met die geopenbaarde Woord van God nie. Daarom gee ons al ons onderwys in volkome onderworpenheid aan die Evangelie van Jesus Christus. Daarom is al ons onderwys - in die godsdienstige en in die wêreldlike vakke-Christelike onderwys.

Christelike onderwys is nie alleen roeping van die Christen nie maar dit is ook die hoogste moontlikheid vir die Christen.

J. CHR. COETZEE. 